\title{
Techno-economic performance assessment of central-grid wind turbines at major geographical locations of Pakistan
}

\author{
Aamir Mehmood \\ Faculty of Mechanical Engineering, University of Engineering and Technology Lahore (FSD Campus)-38000, Pakistan, \\ Department of Systems Engineering and Engineering Management, City University of Hong Kong, Hong Kong, \\ aamir.mehmood08@gmail.com, orcid.org/0000-0003-3932-2915

\section{Zafar Said}

Department of Sustainable and Renewable Energy Engineering, University of Sharjah, Sharjah, United Arab Emirates, zaffar.ks@gmail.com, orcid.org/0000-0003-2376-9309

Adeel Waqas

National University of Sciences and Technology, Islamabad 44000, Pakistan, adeelwaqas@ gmail.com, orcid.org/0000-0002-0892-3972

Waseem Arshad

Failure Analysis Center, Institute of Space Technology, Islamabad-44000, Pakistan, smartengineer42@ gmail.com, orcid.org/0000-0001-9427-0607

Arrived: 01.08.2017 Accepted: 24.09.2017 Published: 25.09.2017

Abstract: This work is focused on techno-economic performance evaluation of grid connected wind turbines of different power ratings (2 MW and $3 \mathrm{MW})$ at six coastline areas of Pakistan using RETScreen software. Software imports the weather data of selected locations from its database reported by National Aeronautics and Space Administration. Software outcomes indicate the unadjusted energy production, gross energy production and capacity factor of wind turbines. Comparative study shows that the wind turbine of either rating installed in Jiwani, having capacity factor $33.7 \%$ (of $2 \mathrm{MW}$ turbine) and 36.8\% (of $3 \mathrm{MW}$ wind turbine) produces $\sim 64 \%$ more gross energy than at Karachi and $\sim 4 \%$ more than that at Ormara location. Financial viability of wind power project installation is evaluated considering economic determinants and life cycle savings. Technical analysis also reveals the amount of electricity exported to grid. Comparative performance of $3 \mathrm{MW}$ and $2 \mathrm{MW}$ wind turbines is evaluated, and $3 \mathrm{MW}$ wind turbine is found more viable and profitable. Jiwani is found the most favorite location for wind power project installation.

Keywords: $\quad$ Wind energy, Wind turbine, Capacity factor, RETScreen, Economics

Cite this paper: $\quad$ Mehmood, A, Said, Z, Waqas, A, Arshad, W. Techno-economic performance assessment of central1(1): 43-55 DOI: 10.30521/jes.347512

(C) 2017 Published by JES peer-review scientific journal at DergiPark (www.dergipark.gov.tr/jes)

\begin{tabular}{r|l} 
Nomenclature & \\
\hline$V$ & Wind Speed \\
$h$ & Height \\
$\rho$ & Air density \\
$P$ & Wind power \\
$C_{p}$ & Power coefficient \\
$\mathrm{GHG}$ & Greenhouse gases \\
$\mathrm{CF}$ & Cash flow \\
$\mathrm{CF}_{0}$ & Zeroth cash flow i.e. investment \\
$\mathrm{CF}$ & $\mathrm{i}^{\text {th }}$ cash flow \\
$\mathrm{NASA}$ & National Aeronautics and Space Administration \\
$\mathrm{NPV}$ & Net present value \\
$\mathrm{IRR}$ & Internal rate of return \\
$\mathrm{BCR}$ & Benefit-cost ratio \\
\hline \hline
\end{tabular}




\section{INTRODUCTION}

Energy plays a vital role in improving the living standard of a nation and to strengthen all economy concerned matters. Energy as a conserved quantity [1] is an important principle behind all science and engineering concepts. Its demand is increasing in an impressive way with continuous expanding urbanization and industrial revolution causing fast economic growth in the world [2]. Global primary energy demand has become almost double during last $\sim 3$ decades [3], and this increase is expected to be $53 \%$ by 2030 [4]. This continuous increasing energy demand was fulfilled by combustion of fossil fuels i.e. liquefied petroleum products $(33.7 \%)$, coal $(30.5 \%)$ and natural gas (24.4\%) [4]. With continued current consumption rate, crude oil and natural gas reserves would run out by $\sim 2052$ and $\sim 2073$ respectively [5] that's why European Union included the production of innovative fuels as one of the main targets in Horizon-2020 projects [6]. In current world energy scenario, renewable energy systems are thought to be the best option to tackle the sustainability and global climate change issues [7]. Nature has gifted this world with several abundant and non-replenish-able sources of energy that are large enough to accomplish current overall energy requirements, and solar and wind are the most salient among them $[8,9]$.

Pakistan is one of the developing nations facing acute power shortfall, and is a part of 10 countries count that account for $66 \%$ of world's such population living without electricity access [10]. Pakistan's primary energy supply largely dependent on fossil fuels [11] i.e. natural gas (49.5\%), liquefied petroleum products (30.8\%). Total of only $10.5 \%$ [11] primary energy is supplied by hydel power. Unfortunately, renewable share of Pakistan energy mix is not even considerable in-spite of having immense wind and solar potential. Coastline areas of Sindh and Balochistan provinces that have maximum wind potential, suffered the worst power crisis situation since long. Still half of Sindh and nine-tenth of Balochistan province population has no access to electric power [10]. Up-to now six wind power projects of total $308.2 \mathrm{MW}$ are in operational status and many projects of total $1140 \mathrm{MW}$ are in installation or pipeline phase as elaborated in Table 2 [12]. Pakistan has $\sim 1046 \mathrm{~km}$ long coastline, starting from Indian border in east to Iranian border in the west as depicted in wind map of Pakistan (Figure 1), that has poor to outstanding wind resource potential range against certain wind speed values as tabulated in Table 1 [13]. It is reported that Ghoro Keti Bandar wind corridor spreading $60 \mathrm{~km}$ along the coastline of Sindh province and more than $170 \mathrm{~km}$ deep towards the land alone has potential of generating more than 60,000 MW [14] electric power.

Table 1. Wind power resource potential classification against certain wind speed [13]

\begin{tabular}{|l|l|c|c|}
\hline Wind Power Class & Resource Potential & Wind Power Density at $50 \mathrm{~m}\left(\mathrm{~W} / \mathrm{m}^{2}\right)$ & Wind Speed at $50 \mathrm{~m}(\mathrm{~m} / \mathrm{s})$ \\
\hline 1 & Poor & $0-200$ & $0.0-5.4$ \\
\hline 2 & Marginal & $200-300$ & $5.4-6.2$ \\
\cline { 2 - 4 } 3 & Fair & $300-400$ & $6.2-6.9$ \\
\cline { 2 - 4 } 4 & Good & $400-500$ & $6.9-7.4$ \\
\hline 5 & Excellent & $500-600$ & $7.4-7.8$ \\
\hline 6 & Outstanding & $600-800$ & $7.8-8.6$ \\
\hline 7 & Superb & $>800$ & $>8.6$ \\
\hline
\end{tabular}

Table 2: Wind power projects in Pakistan [12)

\begin{tabular}{|l|l|l|l|}
\hline Sr.\# & Project Name & $\begin{array}{l}\text { Capacity } \\
\text { (MW) }\end{array}$ & Current Status \\
\hline 1 & FFC Energy Limited & 49.50 & Operational \\
\hline 2 & Zorlu Enerji Pakistan (Pvt.) Limited & 56.40 & Operational \\
\hline 3 & $\begin{array}{l}\text { Three Gorges Pakistan First Wind Farm } \\
\text { (Pvt.) Limited }\end{array}$ & 49.50 & Operational \\
\hline 4 & Foundation Wind Energy II (Pvt.) Limited & 50.00 & Operational \\
\hline 5 & Foundation Wind Energy-I Limited & 50.00 & Operational \\
\hline 6 & Sapphire Wind Power Company Limited & 52.80 & Operational \\
\hline 7 & Projects Under Construction (Achieved Financial Close) \\
\hline 7 & Yunus Energy Limited & 50.00 & $\begin{array}{l}\text { Signed EPA with CPPA/NTDCL and IA with } \\
\text { GOP (AEDB) }\end{array}$ \\
\hline
\end{tabular}




\begin{tabular}{|c|c|c|c|}
\hline 8 & $\begin{array}{l}\text { Sachal Energy Development (Pvt.) } \\
\text { Limited }\end{array}$ & 49.50 & $\begin{array}{l}\text { Signed EPA with CPPA/NTDCL and IA with } \\
\text { GOP (AEDB) }\end{array}$ \\
\hline 9 & Metro Power Company Limited & 50.00 & $\begin{array}{l}\text { Signed EPA with CPPA/NTDCL and IA with } \\
\text { GOP (AEDB) }\end{array}$ \\
\hline 10 & Tapal Wind Energy Pvt. Limited & 30.00 & $\begin{array}{l}\text { Signed EPA with CPPA/NTDCL and IA with } \\
\text { GOP (AEDB) }\end{array}$ \\
\hline 11 & United Energy Pakistan Pvt. Limited & 99.00 & $\begin{array}{l}\text { Signed EPA with CPPA/NTDCL and IA with } \\
\text { GOP (AEDB) }\end{array}$ \\
\hline 12 & Hydro China Dawood Power Pvt. Limited & 49.50 & $\begin{array}{l}\text { Signed EPA with CPPA/NTDCL and IA with } \\
\text { GOP (AEDB) }\end{array}$ \\
\hline 13 & Master Wind Energy Limited & 49.50 & $\begin{array}{l}\text { Signed EPA with CPPA/NTDCL and IA with } \\
\text { GOP (AEDB) }\end{array}$ \\
\hline 14 & Tenega Generasi Limited & 49.50 & $\begin{array}{l}\text { Signed EPA with CPPA/NTDCL and IA with } \\
\text { GOP (AEDB) }\end{array}$ \\
\hline 15 & Gul Ahmed Wind Power Limited & 50.00 & $\begin{array}{l}\text { Signed EPA with CPPA/NTDCL and IA with } \\
\text { GOP (AEDB) }\end{array}$ \\
\hline \multicolumn{4}{|c|}{ Projects in Pipeline } \\
\hline 16 & Jhampir Wind Power Limited & 50.00 & $\begin{array}{l}\text { Signed EPA With CPPA/NTDCL, } \\
\text { Negotiation yet to be started }\end{array}$ \\
\hline 17 & Hawa Energy Pvt. Limited & 50.00 & $\begin{array}{l}\text { Signed EPA With CPPA/NTDCL, } \\
\text { Negotiation yet to be started }\end{array}$ \\
\hline 18 & Hartford Alternative Energy Pvt. Limited & 50.00 & Stage not reached yet \\
\hline 19 & $\begin{array}{l}\text { Three Gorges Second Wind Farm } \\
\text { Pakistan Limited }\end{array}$ & 49.50 & Stage not reached yet \\
\hline 20 & $\begin{array}{l}\text { Three Gorges Third Wind Farm Pakistan } \\
\text { (Pvt.) Limited }\end{array}$ & 49.50 & Stage not reached yet \\
\hline 21 & $\begin{array}{l}\text { Tricon Boston Consulting Corporation } \\
\text { (Pvt.) Limited (A) }\end{array}$ & 50.00 & Stage not reached yet \\
\hline 22 & $\begin{array}{l}\text { Tricon Boston Consulting Corporation } \\
\text { (Pvt.) Limited (B) }\end{array}$ & 50.00 & Stage not reached yet \\
\hline 23 & $\begin{array}{l}\text { Tricon Boston Consulting Corporation } \\
\text { (Pvt.) Limited (C) }\end{array}$ & 50.00 & Stage not reached yet \\
\hline 24 & Zephyr Power Pvt. Limited & 50.00 & Stage not reached yet \\
\hline 25 & Western Energy Pvt. Ltd & 50.00 & Stage not reached yet \\
\hline 26 & China Sunec Energy (Pvt.) Limited & 50.00 & EPA \& IA Negotiation yet to be started \\
\hline 27 & Burj Wind Energy (Pvt.) Limitd & 14.00 & Stage not reached yet \\
\hline 28 & Trans-Atlantic Energy (Pvt.) Limited & 50.00 & Stage not reached yet \\
\hline 29 & Shaheen Foundation PAF & 50.00 & Stage not reached yet \\
\hline
\end{tabular}

Current study aims to have a detail life cycle analysis of grid connected wind turbines having different power ratings ( $2 \mathrm{MW}$ and $3 \mathrm{MW}$ ) using RET Screen wind energy model at six major latitude locations selected at Pakistan wind corridor named: Karachi, Hyderabad, Badin, Jiwani, Ormara and Gwadar. Three of selected locations are a part of Balochistan province coastline named: Jiwani, Ormara and Gwadar; while remaining three belong to Sindh province. Work is focused on:

Comparative performance evaluation of wind turbines having different power ratings in terms of their technical parameters i.e. capacity factor, gross energy production and electric power exported to grid. Economics of modelled systems is evaluated on the basis of determinants i.e. IRR, payback period, NPV, BCR and life cycle savings.

Analysis also reveals how much GHG emissions reduction is possible? 


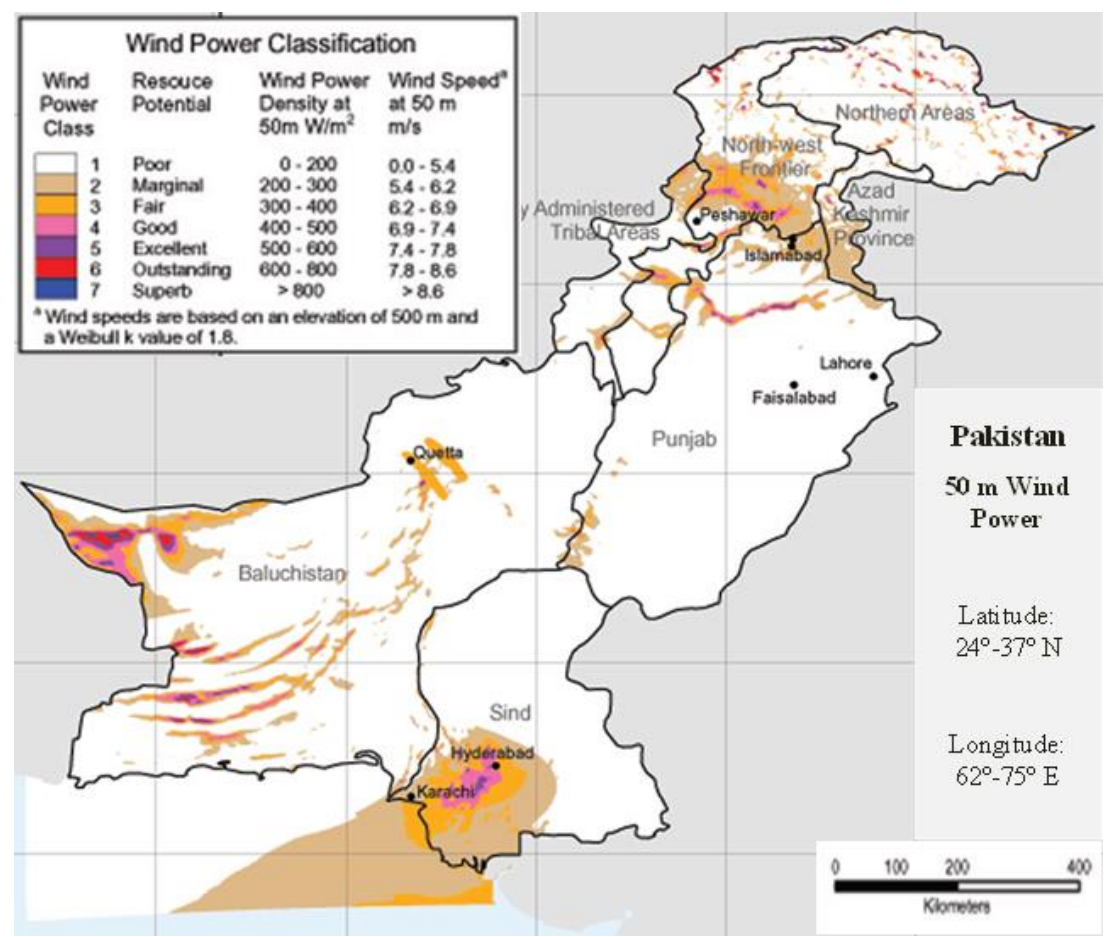

Figure 1. Wind power density map of Pakistan [13]

\section{CLIMATE INFORMATION OF SELECTED LOCATIONS OF PAKISTAN}

Climate information of any location means a lot in case of renewable energy projects. In wind projects evaluation; wind speed is one of the most important weather information that is actually an input force. RET Screen software imports the climate information of any selected location from its database reported by NASA. Climatic information of different coastline areas selected for current study are tabulated in Table 3 .

Table 3. Climatic information of wind turbine project sites in Pakistan.

\begin{tabular}{|l|c|c|c|c|c|c|}
\hline Property & \multicolumn{5}{|c|}{ Climatic data of the location } \\
\hline Location & Karachi & Hyderabad & Badin & Jiwani & Ormara & Gwadar \\
\hline Latitude $\left({ }^{\circ} \mathrm{N}\right)$ & 24.9 & 25.4 & 24.7 & 25.1 & 25.2 & 25.1 \\
\hline Longitude $\left({ }^{\circ} \mathrm{E}\right)$ & 67.1 & 68.4 & 68.8 & 61.8 & 64.6 & 62.3 \\
\hline Ambient temperature (Annual) ${ }^{\circ} \mathrm{C}$ & 26.1 & 26.5 & 27.0 & 25.5 & 24.6 & 25.2 \\
\hline $\begin{array}{l}\text { Average annual wind speed }(\mathrm{m} / \mathrm{s}) \text { [measured at } \\
10 \mathrm{~m} \text { ] }\end{array}$ & 3.5 & 3.5 & 3.2 & 4.1 & 4.0 & 4.1 \\
\hline Atmospheric pressure-annual $(\mathrm{kPa})$ & & & & & \\
\hline
\end{tabular}

\section{METHODOLOGY TO EVALUATE THE WIND TURBINE PERFORMANCE}

RETScreen software based on f-chart method, developed by Natural Resources Canada's CANMET Energy Diversification Research Laboratory (CEDRL), is used worldwide to figure out the viability of potential renewable energy based projects at the first. In current work, techno-economic viability of 2 MW and $3 \mathrm{MW}$ wind turbines at different coastline areas is carried out using wind energy model of RETScreen software. The methodology adopted to evaluate the performance of central-grid wind turbines case study is shown in Figure 2; involving all input parameters and estimated outcomes. 


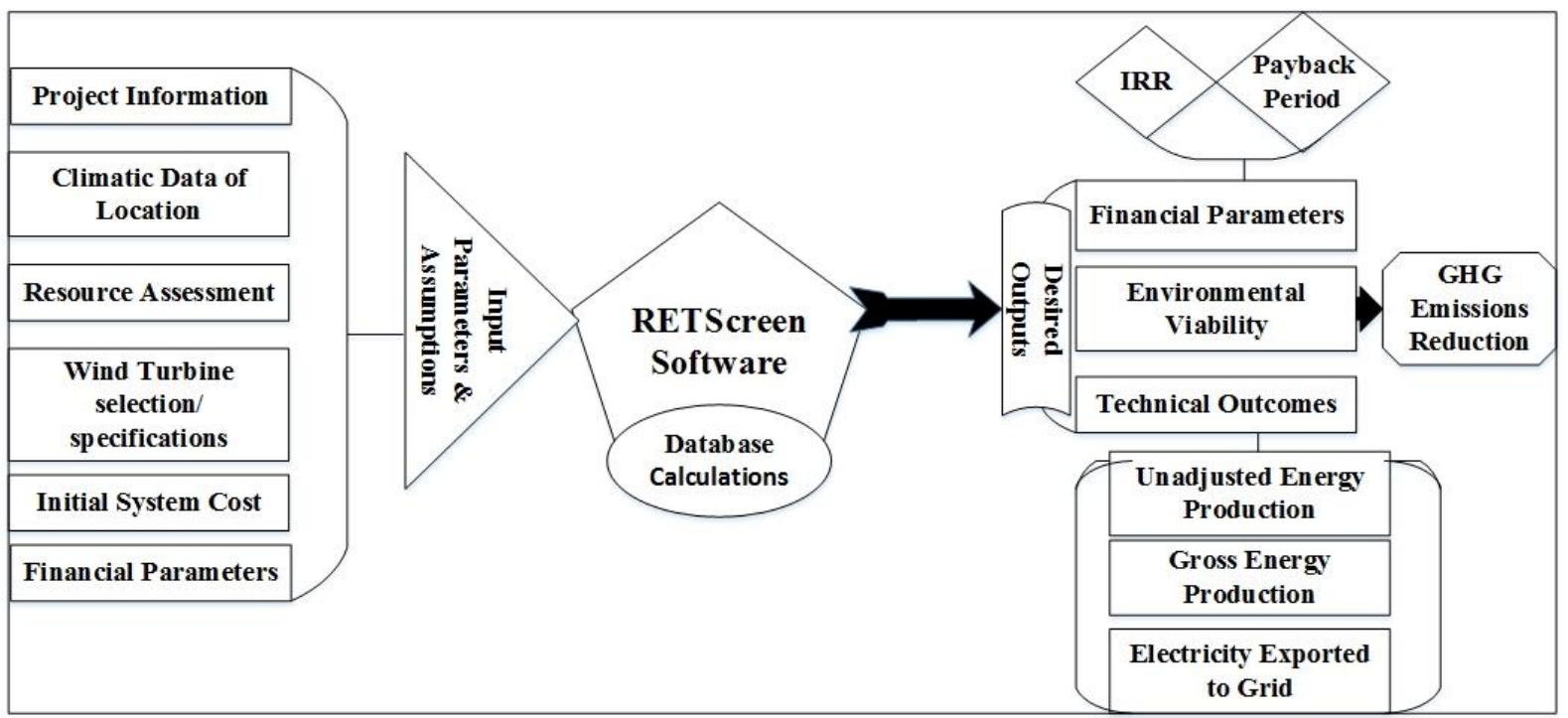

Figure 2: Methodology adopted to evaluate the comparative performance of central-grid wind turbines.

Wind is one of the cleanest technologies being and could be used for power generation. Wind turbine is the key element of any wind power project. That's why a lot of work has been carried out concerned with wind turbine size and still continues. In start to the mid of 1980's, available wind turbine size was less than $100 \mathrm{~kW}$ [15]. By the end of $2^{\text {nd }}$ last decade of $19^{\text {th }}$ century, this available wind turbine size had increased to $500 \mathrm{~kW}$ [15]. After that, wind turbine size increased progressively and reached to $1000 \mathrm{~kW}$ by mid-1990s. Now turbines with more than $8 \mathrm{MW}$ generation capacity having $180 \mathrm{~m}$ rotor diameter have been manufactured [16].

The wind is fuel- unlike fossil fuels it is both free and clean, but otherwise it is just the same. It drives the wind turbine that exports electric power to grid. Windmill power generation requires continuous wind flow at a rated speed. This is very difficult because wind speed fluctuates over short period of time and dependent on height above the ground. Wind speed at certain height above the ground can be estimated using Hellmann exponent law [17];

$$
V(h) / V_{10}=(h / 10)^{\alpha} \alpha
$$

In equation (1), $V(h)$ represents the wind speed at any certain height while $V_{10}$ is wind speed at height of $10 \mathrm{~m}$. The Hellmann exponent's $(\alpha)$ value is function of roughness of terrain, but in case of flatopen country this exponent's value is equivalent to one seventh. The available power in wind at any speed rate per unit area can be estimated using [18];

$$
P=1 / 2 \rho V^{3}
$$

It is not possible to extract the total available wind power by any wind machine. So the maximum power could be extracted through any wind machine is limited by Betz relation [18]. The maximum extractable power per meter is estimated using following relation;

$$
P_{\max }=1 / 2 \rho C_{p} V^{3} \mathrm{Wm}^{-2}
$$

In Equation 3; $C_{p}$ is power coefficient assigned by Betz relation equivalent to $16 / 27$ for the maximum wind machine performance. Efficiency of some common types of wind turbines against tip speed ratio (tsr) is depicted in Figure 3 [19]. 


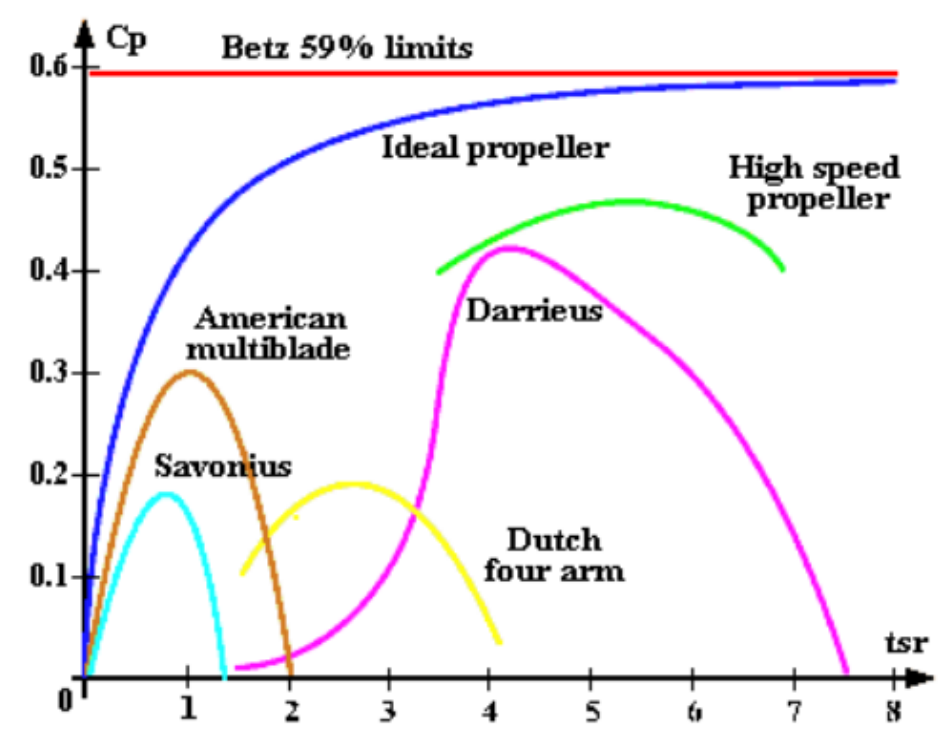

Figure 3. Efficiency of some wind turbines against tip speed ratio [19]

Input parameters used for evaluating the performance of wind turbines of different ratings are listed in Table 4 and

Table 5. Wind turbine selection is made keeping in view its characteristic features suitability and concern of availability. Financial input parameters required by software to figure out the viability of wind turbine system involves; electricity export rate announced by National Electric Power Regulatory Authority equals to $16.207 \mathrm{PKR} / \mathrm{kWh}$ [14], average fuel cost escalation rate that is $4.10 \%$ [20] in Pakistan, average inflation rate equals to 2.26\% [20], discount rate has been raised to $9.5 \%$ by State Bank of Pakistan, and interest rate currently exists in bank trading is 6.0\% [21]. The total project investment including engineering, procurement and construction (EPC) cost and non-EPC costs estimated equals to 255.016 PKR Million/MW [22].

Table 4. Characteristic parameters of selected wind turbines.

\begin{tabular}{|l|l|l|l|}
\hline Parameters & Units & \multicolumn{2}{|c|}{ Value } \\
\hline Power capacity & $\mathrm{MW}$ & 2 & 3 \\
\hline Hub height & $\mathrm{m}$ & 108 & 135 \\
\hline Rotor diameter of turbine & $\mathrm{M}$ & 82 & 101 \\
\hline Swept area per turbine & $\mathrm{m}^{2}$ & 5,281 & 8,012 \\
\hline
\end{tabular}

Table 5. RETScreen wind energy model input financial parameters.

\begin{tabular}{|l|l|}
\hline Factor & Value \\
\hline Total project cost & $255.016 \mathrm{PKR}$ Million/MW \\
\hline Electricity export rate & $16.207 \mathrm{PKR} / \mathrm{kWh}$ \\
\hline Fuel cost escalation rate & $4.10 \%$ \\
\hline Inflation rate & $2.26 \%$ \\
\hline Discount rate & $6.0 \%$ \\
\hline
\end{tabular}

\section{RESULTS and DISCUSSIONS}

Results based on system's unadjusted energy production, gross energy production, electricity exported to grid, project IRR, payback periods, NPV, BCR, life cycle savings, and GHG emissions reduction are presented and discussed in this section. These results are discussed in the following sections: Technical Analysis, Economic Behavioural Study, Environmental Effect.

\subsection{Technical analysis}

Technical performance assessment of wind turbines is carried out in terms of unadjusted energy production, gross energy production, capacity factor and electric power exported to grid. 
Power produced by a wind turbine is largely depends upon speed of wind that causes the turbine rotor motion. As we move above the ground surface, wind speed increases progressively with the increase in height as shown in Figure 4. The comparison of wind speed curves for $10 \mathrm{~m}$ and $108 \mathrm{~m}$ heights shows that there is $\sim 34 \%$ increase in wind speed against $98 \mathrm{~m}$ change in height. Furthermore, the analysis of wind speed curves for $108 \mathrm{~m}$ and $135 \mathrm{~m}$ heights elaborates that wind speed increases by $42 \sim 45 \%$ against $27 \mathrm{~m}$ further increase in height after $108 \mathrm{~m}$ altitude.

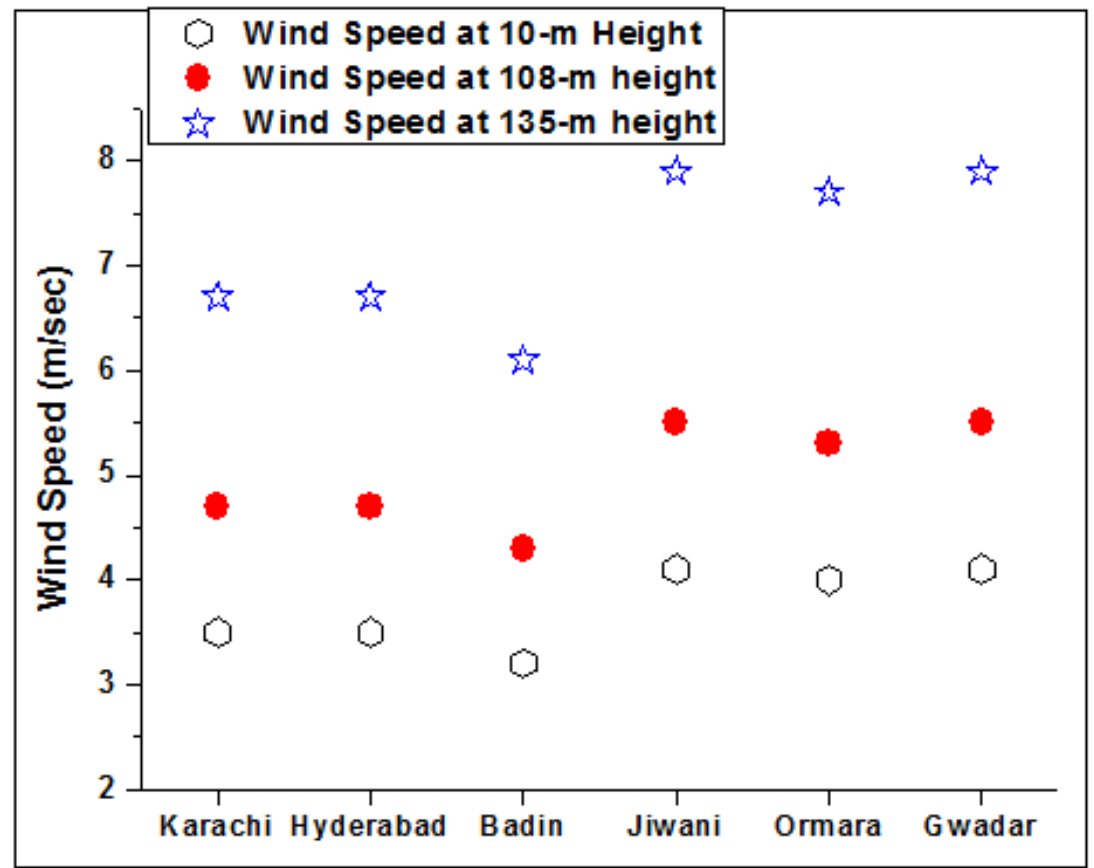

Figure 4. Variations in wind speed against height above the ground

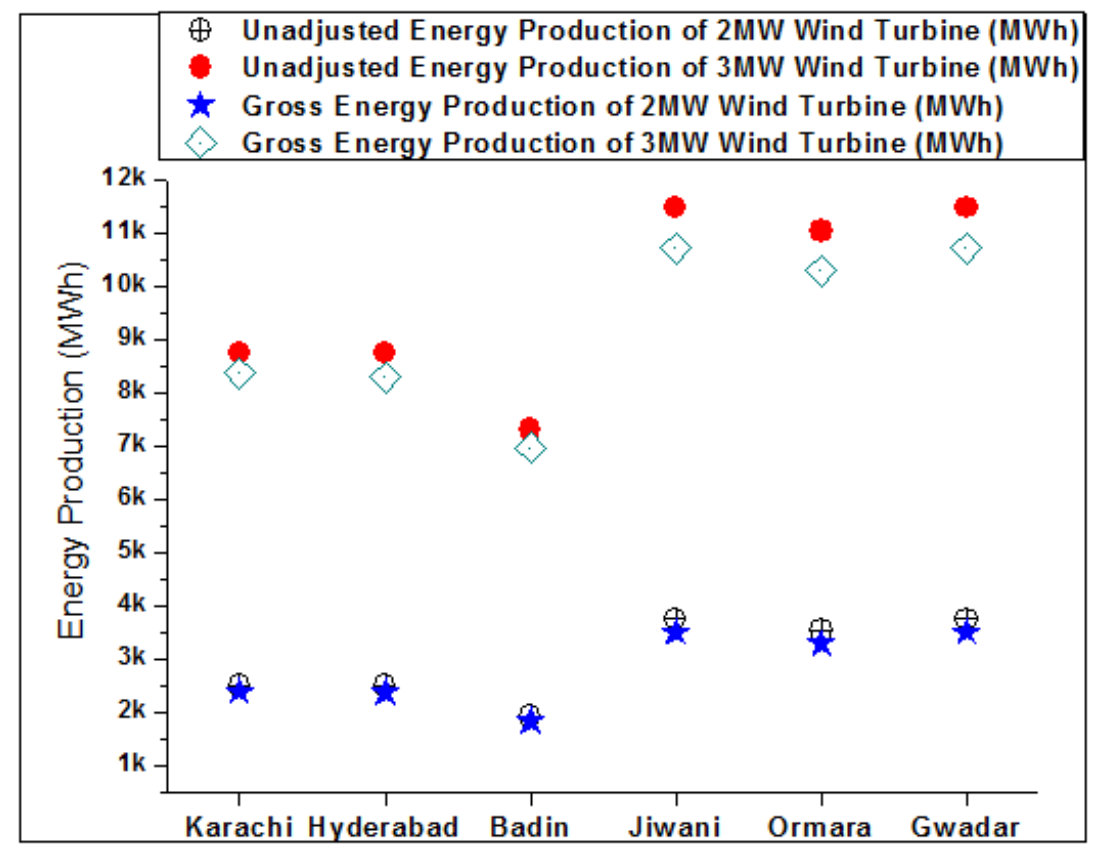

Figure 5. Unadjusted and gross energy production of wind turbines.

Unadjusted energy and gross energy produced by either of two different power rated wind turbines are depicted in Figure 5, while capacity factor of each turbine at certain location and final electricity exported to grid by each of gird connected wind turbines are shown in Figure 6. Analysis of these figures shows that the energy produced and final exported electric power to grid by either of the turbines at certain location directly correspond to available wind speed i.e. greater the value of wind speed 
available, larger would be the value of gross energy produced and consequently higher MWhs would be exported to grid. Capacity factor of wind turbine is another indication parameter of wind turbine's performance. Higher the value of capacity factor means greater would be the amount of electric power exported by installed wind turbine to grid as evident in Figure 6.

Comparative technical analysis of Figure 5 and Figure 6 shows that Jiwani and Gwadar are the most favorable locations among all with highest capacity factor and maximum exported electric power values for both $2 \mathrm{MW}$ and 3MW rated wind turbines, while Badin is the least feasible one. Comparative study of two provinces elaborates that all the three under-examined cities of Balochistan province are technically more viable for wind turbine installation with $\sim 35 \%$ greater electric power generation value and collectively 19 28\% higher capacity factor compared to the cities of Sindh province outcome.

The comparative performance study of different power rated wind turbines shows that the wind turbine with $3 \mathrm{MW}$ power rating is more technically viable than $2 \mathrm{MW}$ wind turbine with 15 19\% higher capacity factor. Electricity exported to grid by 3 MW wind turbine is $205 \sim 280 \%$ greater in value than that of $2 \mathrm{MW}$ wind turbine. Reason associated with the fact is greater the height of turbine hub due to which speed of wind strikes the $3 \mathrm{MW}$ turbine rotor is $42 \sim 45 \%$ higher in value than that strikes to 2 MW wind turbine rotor.

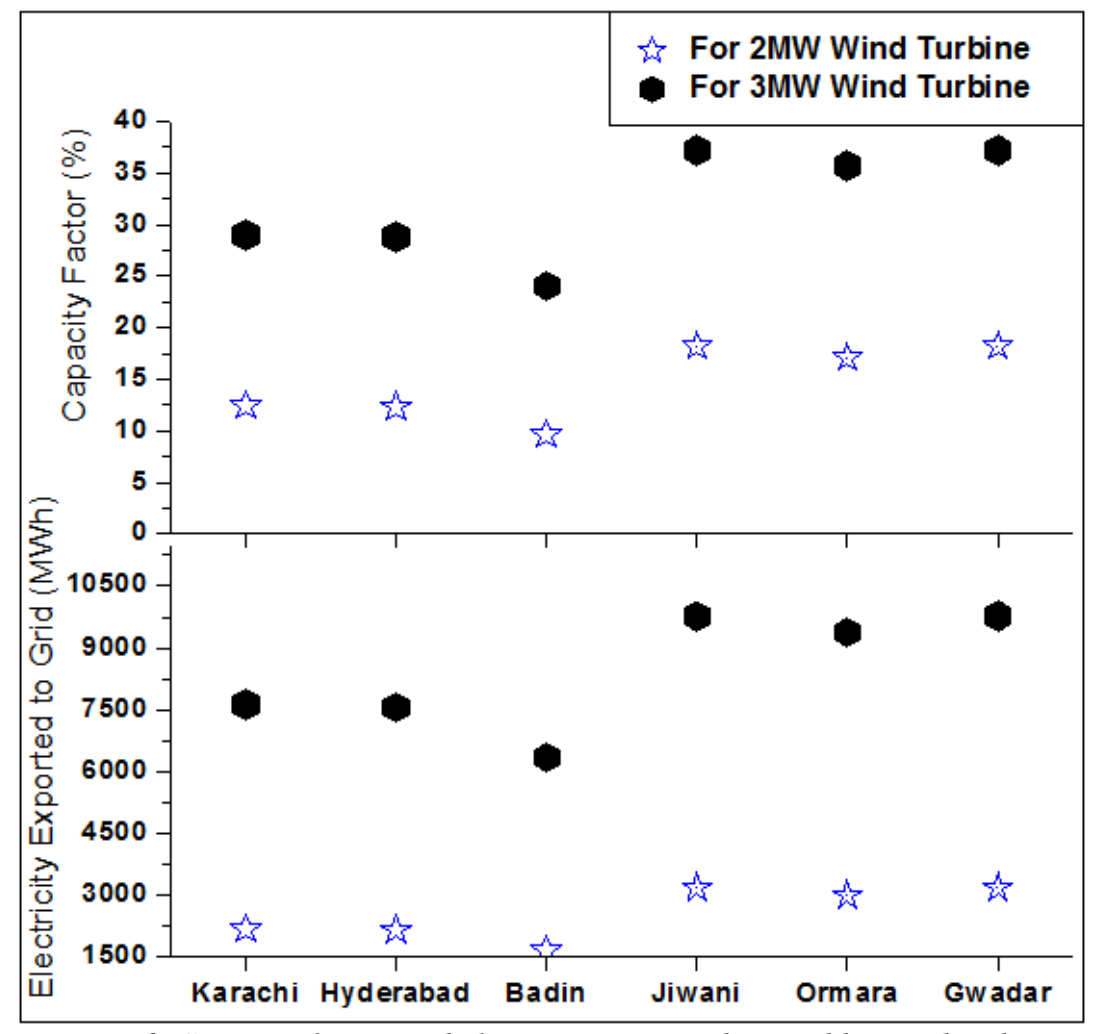

Figure 6. Capacity factor and electricity exported to grid by wind turbines

\subsection{Economic behavioral study}

Economic analysis of wind turbines having different power ratings is carried out considering economic determinants i.e. IRR, payback period, NPV, BCR and life cycle savings as deciding parameters, to find out whether it is financially viable to install a wind turbine at certain location or not?

IRR and NPV are the most influencing economic determinants according to economist approach, where IRR is a form of discounted rate that equals the net present value of a project cash flows to zero and often is used in capital budgeting. While NPV meant for coming cash flows that are subsidized at certain discount rate. These economic determinants can be calculated using [23];

$$
-C F_{0}+\sum_{i=1}^{t}\left[\frac{C F_{i}}{(1+r)^{i}}\right]=N P V=0
$$

Where; $i=1,2,3 \ldots, t$ 
Payback period and annual life cycle savings are important economic determinants for a project with respect to investor's insight. Payback period tells about the time length to recover initial investment of the project. It can be calculated simply by dividing the project cost to annual cash flows. On other hand, annual life cycle savings account for nominal yearly based savings that are calculated considering project's NPV, project proposed life period and discount rate value.

Analysis of Figure 7, Figure 8, Figure 9 and Figure 10 show that all economic determinants favor the Jiwani and Gwadar locations the most for either of two different power rated wind turbines installation with maximum IRR values, minimum payback periods and relative higher values of NPV, BCR and life cycle savings. Badin is economically least feasible location with minimum values of IRR, NPV, BCR and life cycle savings, and maximum payback period.

In perspective of comparative analysis between Balochistan and Sindh provinces, it is concluded that all the three coastline locations of Balochistan province are economically more viable than of Sindh locations in terms of all economic determinants with higher NPV values, 16 17\% greater IRR values, collectively 35 57\% less payback periods, 0.93 1.39 greater BCR values, and relatively higher life cycle savings are possible (evident from Figure 7, Figure 8, Figure 9 and Figure 10).

The comparative analysis of wind turbines having different power ratings shows that wind turbine having $3 \mathrm{MW}$ power rating is more viable to install than $2 \mathrm{MW}$ wind turbine with positive NPV values, $11 \sim 13 \%$ higher IRR values, 52 60\% less payback periods, and 0.71 0.94 higher BCR for all selected locations of Pakistan. Even life cycle savings are possibly positive only in case of $3 \mathrm{MW}$ wind turbine installation compared to $2 \mathrm{MW}$ wind turbine. It is also economically more profitable to install $3 \mathrm{MW}$ wind turbine in Balochistan province territory as payback period curve for $3 \mathrm{MW}$ wind turbine shows sharp decline for Jiwani, Ormara and Gwadar; on other hand curves representing NPV, BCR and life cycle savings for $3 \mathrm{MW}$ wind turbine influentially raises for three latitude positions of Balochistan province compared to the curves for Sindh province locations (evident from Figure 7, Figure 8, Figure 9 and Figure 10). The reason that makes a system economically favorable or unfavorable is its technical outcomes: higher capacity factor value leads to greater energy production that will consequently result in greater amount of electric power exported to grid and vice versa.

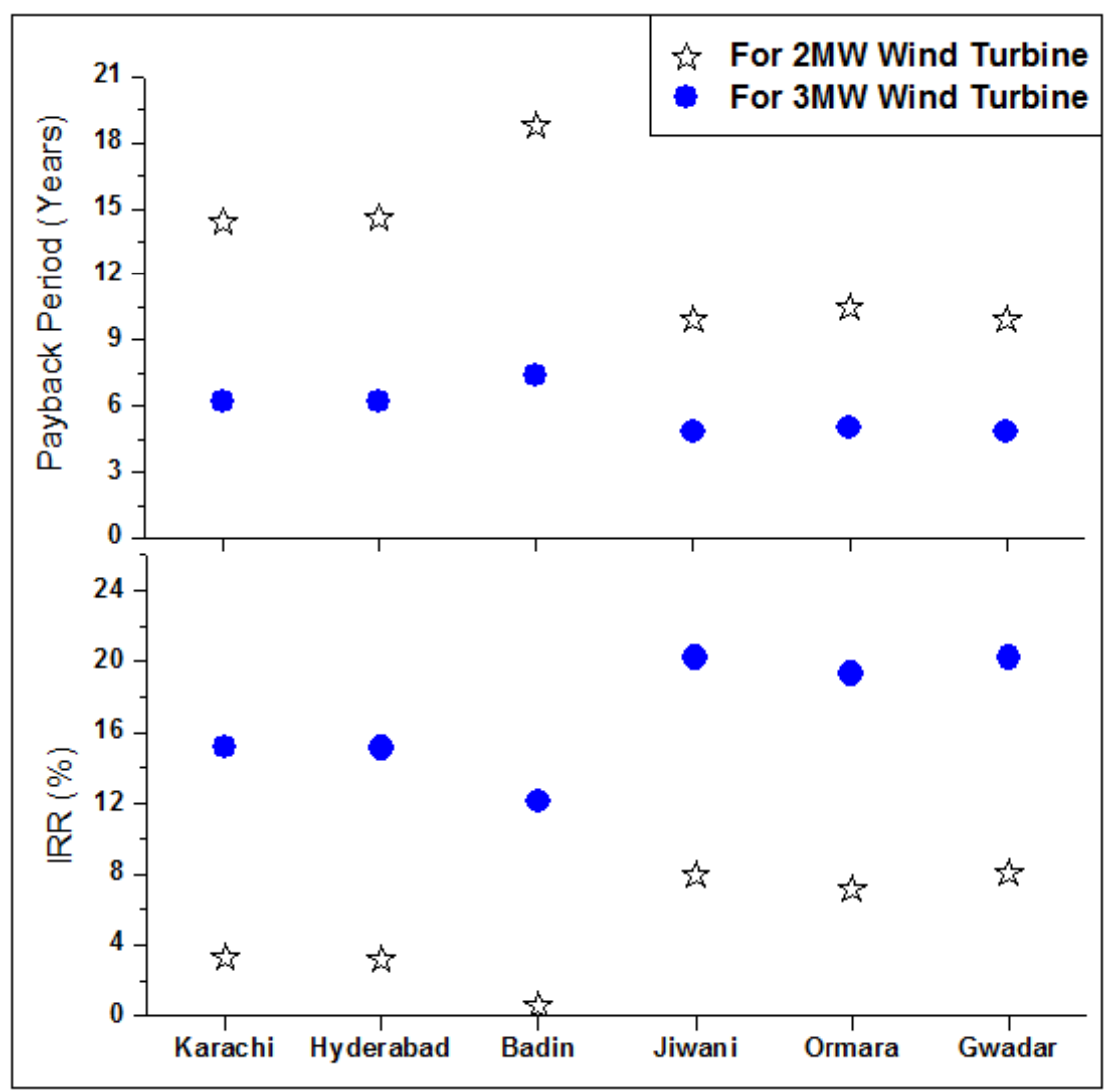

Figure 7. Economic behavioral study of wind turbines in terms of IRR and payback period 


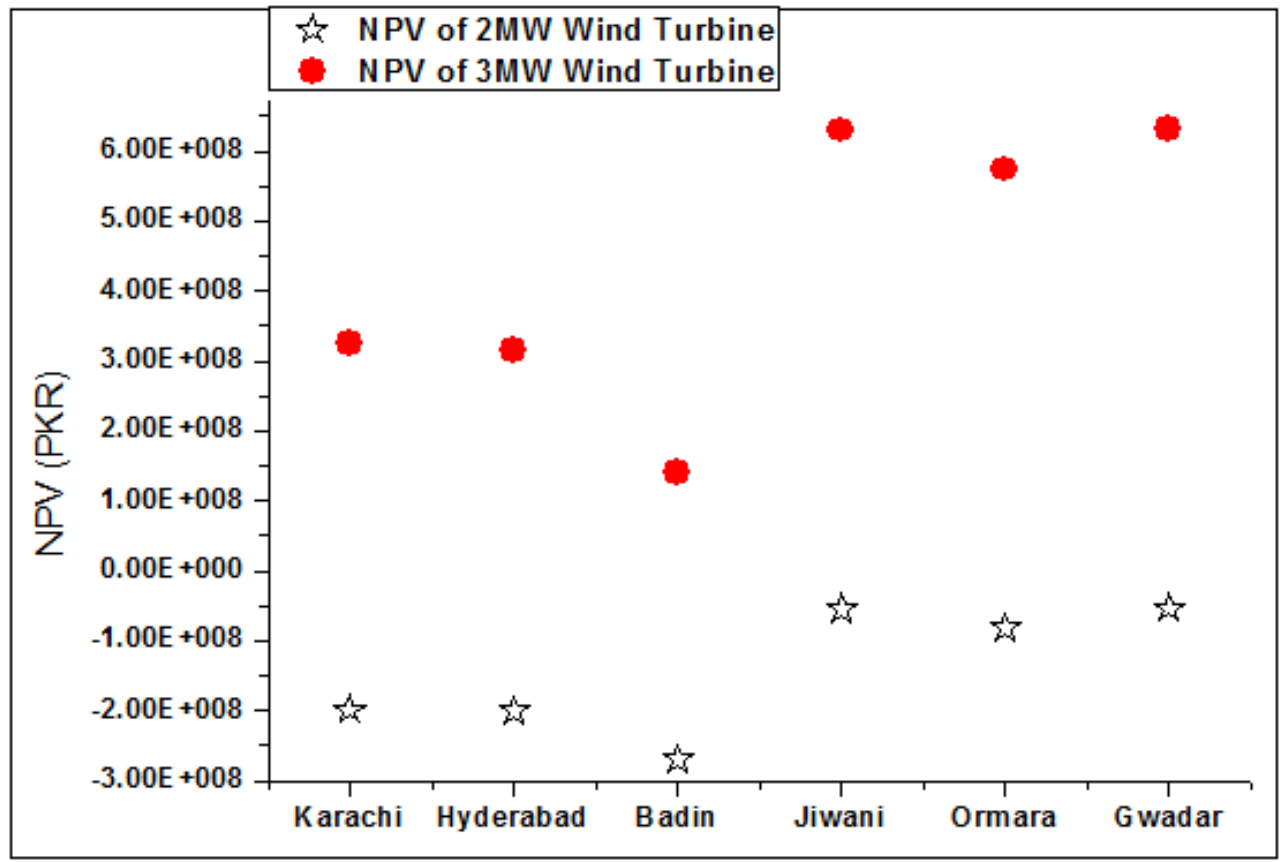

Figure 8. Project NPV of different power rated wind turbines for selected locations

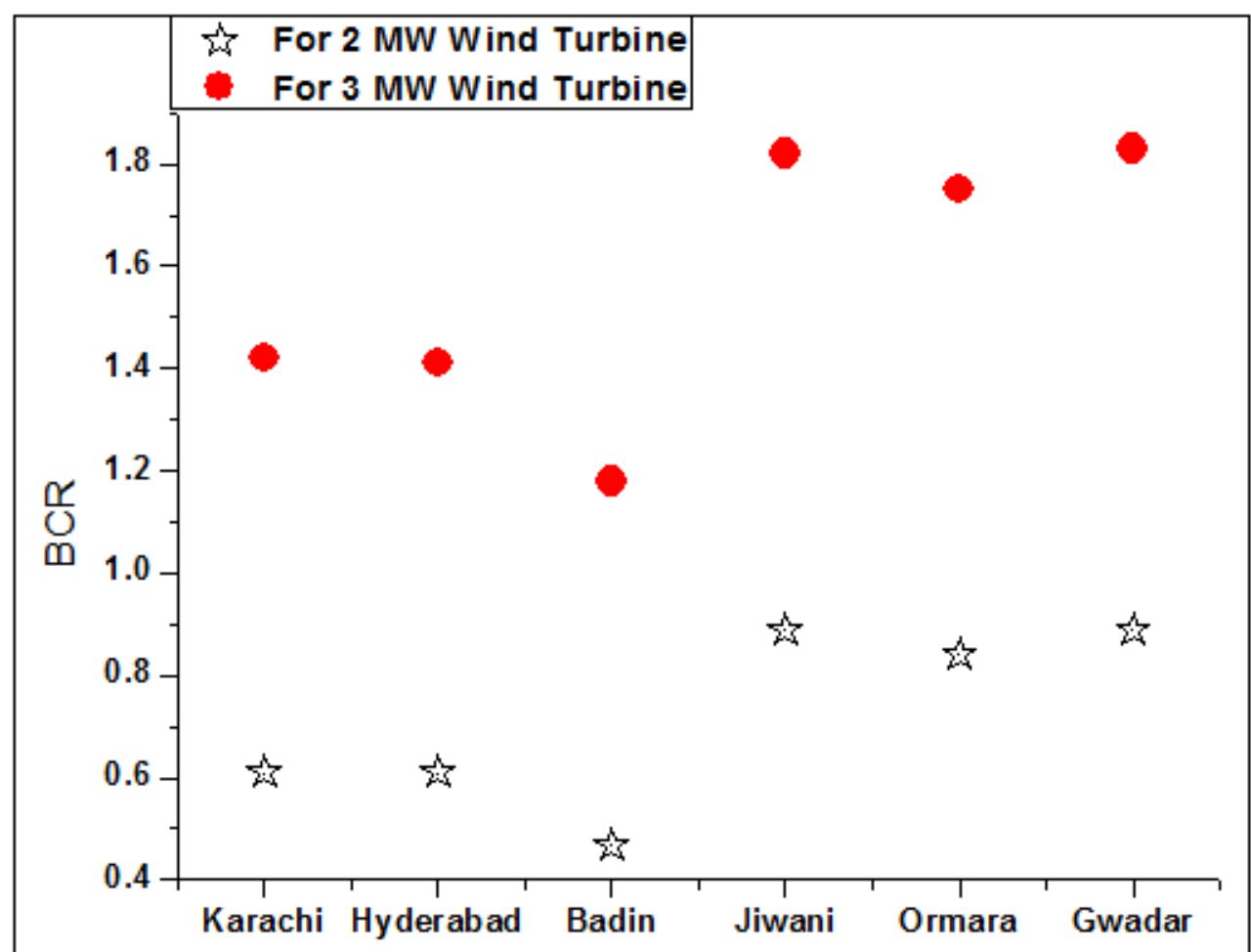

Figure 9. Benefit-cost ratios of $2 M W$ and $3 M W$ wind turbines 


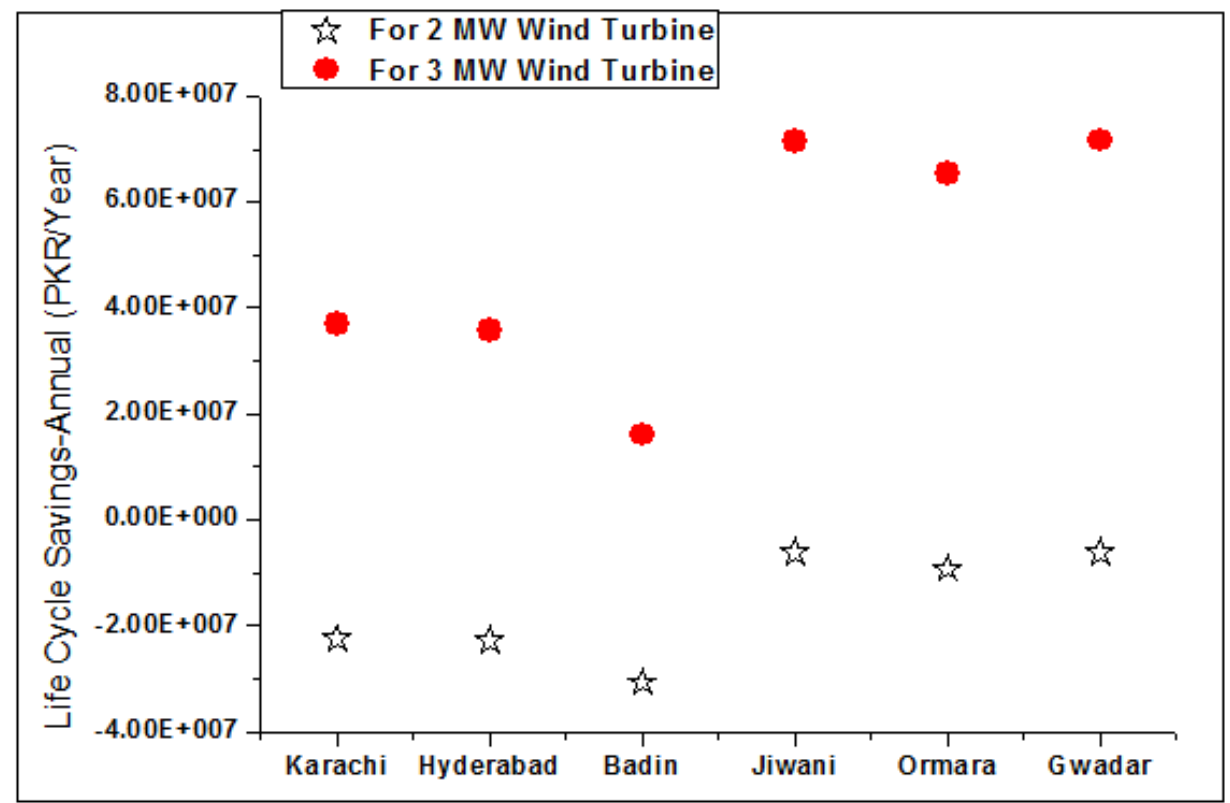

Figure 10. Life cycle savings due to $2 M W \& 3 M W$ wind turbine installation

\subsection{Environmental effect}

GHG emission is a great concern for the entire world. It remained the most discussed issue particularly during last decade, that's why many protocols and standards have been set to control the emissions. Wind is the one of the cleanest technologies among all fuels including both renewables and nonrenewables. GHG emissions reduction possible through installation of either of the two different power rated wind turbines at any of the selected locations is depicted in Figure 11. Analysis of Figure 11 shows that 400 900 $\mathrm{tCO}_{2}$ and 1600 2600 $\mathrm{tCO}_{2}$ GHG emissions could be reduced through installation of a 2 MW and 3 MW wind turbine respectively. The comparative analysis of two different power rated wind turbines reveals that the installation of a 3 MW wind turbine results in 205 280\% greater GHG emissions reduction at certain location than that of a $2 \mathrm{MW}$ wind turbine. The reason of this enhanced GHG emissions reduction value is exported amount of electricity produced by wind turbine instead of fossil fuel consumption.

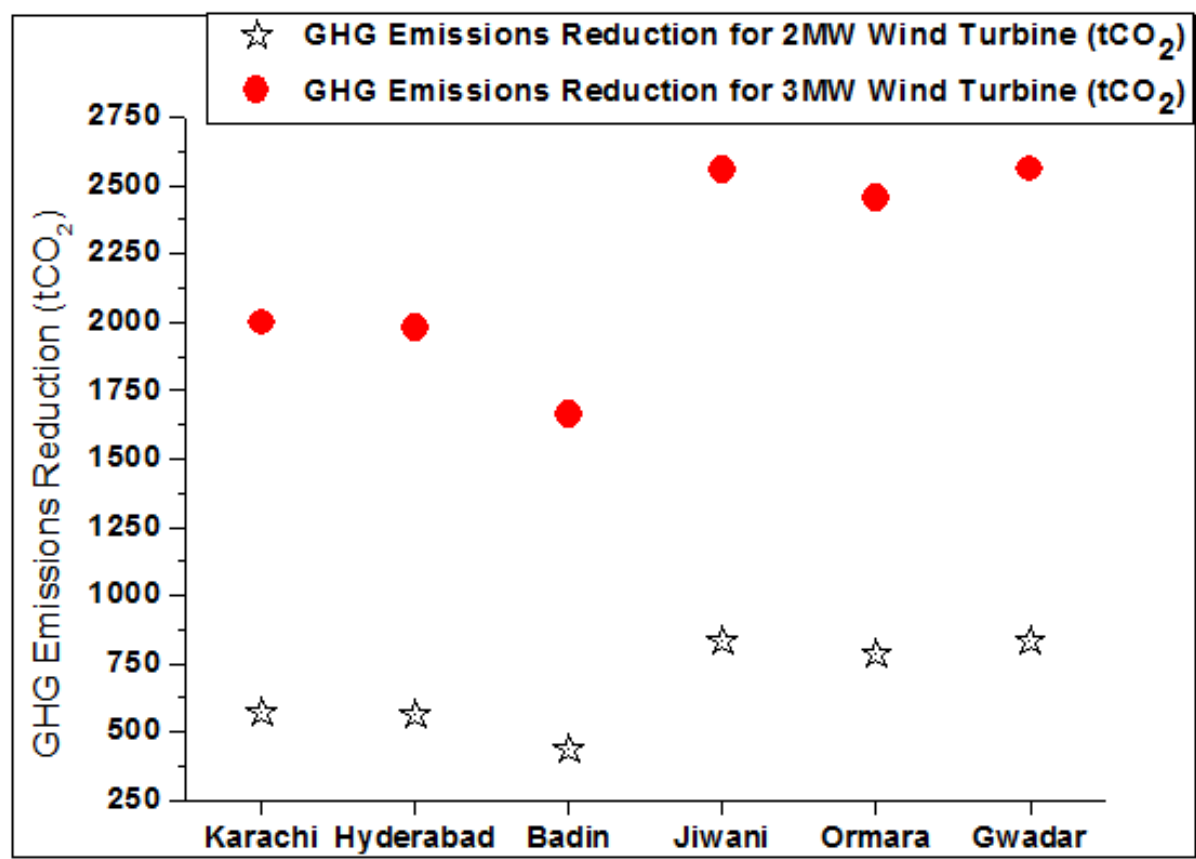

Figure 11. Environmental effect of wind turbine installation in form of GHG emissions reduction 


\section{CONCLUSIONS}

Performance of wind turbines having $2 \mathrm{MW}$ and $3 \mathrm{MW}$ power ratings is evaluated using RETScreen simulation approach at six selected coastline areas of Pakistan. For this purpose, a new simulation methodology is developed that can be used for evaluating technical and especially economic perspectives of any wind energy model. After analyzing the technical, financial and environmental aspects of RETScreen wind energy model, it is concluded that Jiwani and Gwadar are the most feasible coastline areas while Badin is the least feasible for either of wind turbines installation. Among Balochistan and Sindh provinces, Balochistan has more attractive coastline for wind technology installation than of Sindh with positive NPV and life cycle savings stats. It is revealed that after a certain height above the ground, increase in wind speed is much progressive than in the start as moving from $10 \mathrm{~m}$ to $108 \mathrm{~m}$ accompanies only $34 \%$ increase, while moving from $108 \mathrm{~m}$ to $135 \mathrm{~m}$ height above the ground accompanies $42 \sim 45 \%$ increase in wind speed.

The comparative performance analysis of $2 \mathrm{MW}$ and $3 \mathrm{MW}$ wind turbines revealed that $3 \mathrm{MW}$ wind turbine is $15 \sim 19 \%$ more efficient in terms of capacity factor and produces $205 \sim 280 \%$ more electric power with consequently positive NPV and life cycle savings stats, greater than one BCR values, $52 \sim 60 \%$ less payback period compared to that of $2 \mathrm{MW}$ wind turbine with negative NPV values and less than one BCR values. Also installation of either power rated wind turbine would result in appreciable GHG emissions reduction lies in 400-2600 $\mathrm{tCO}_{2}$ range.

\section{Acknowledgements}

The authors would like to acknowledge the research departments of collaborative institutes for providing necessary facilities and allowing sharing research material for carrying out current work.

\section{REFERENCES}

[1] Merkisz J, Fuc P, Lijewski P, Ziolkowski A, Wojciechowski KT. The Analysis of Exhaust Gas Thermal Energy Recovery Through a TEG Generator in City Traffic Conditions Reproduced on a Dynamic Engine Test Bed. Journal of Electronic Materials. 2015;44(6):1704-15.

[2] Zhen J, Huang G, Li W, Wu C, Liu Z. An optimization model design for energy systems planning and management under considering air pollution control in Tangshan City, China. Journal of Process Control. 2016; 47:58-77.

[3] BP Statistical Review of World Energy-2015 British Petroleum, 2015.

[4] World Energy Outlook-2015. International Energy Agency, 2015.

[5] Ashraful AM, Masjuki H, Kalam M, Fattah IR, Imtenan S, Shahir S, et al. Production and comparison of fuel properties, engine performance, and emission characteristics of biodiesel from various non-edible vegetable oils: A review. Energy Conversion and Management. 2014; 80:202-28.

[6] Rivarolo M, Bellotti D, Magistri L, Massardo A. Feasibility study of methanol production from different renewable sources and thermo-economic analysis. International Journal of Hydrogen Energy. 2016.

[7] Ramli MA, Hiendro A, Al-Turki YA. Techno-economic energy analysis of wind/solar hybrid system: Case study for western coastal area of Saudi Arabia. Renewable Energy. 2016; 91:374-85.

[8] Düz H. Storing Solar Energy Inside Compressed Air Through a Heat Machine Mechanism. Gazi University Journal of Science. 2016;29(2):245-51.

[9] Karadeniz A, Eker MK. Rüzgar ve Termik Santrallerden Oluşan Enerji Sistemlerinde Ekonomik Güç Dağılımının Big-Bang Big-Crunch, PSO ve IMO Algoritmaları ile İrdelenmesi, sayfa: 261-268. Politeknik Dergisi. 2016;19(3).

[10] Siddique S, Wazir R. A review of the wind power developments in Pakistan. Renewable and Sustainable Energy Reviews. 2016; 57:351-61.

[11] Pakistan Energy year book-2014. HDIoP, Ministry of Petroleum and Natural Resources, GoP., 2015.

[12] AEDB. Wind Technologies; Alternate Energy Development Board, Ministry of Water and Power, Government of Pakistan.

[13] Butti K, Perlin J. Early solar water heaters. A Golden Thread. 1979:117-27.

[14] Butti K, Perlin J. A golden thread: 2500 years of solar architecture and technology: Cheshire books Palo Alto, CA, USA; 1980.

[15] Joselin Herbert GM, Iniyan S, Sreevalsan E, Rajapandian S. A review of wind energy technologies. Renewable and Sustainable Energy Reviews. 2007;11(6):1117-45.

[16] Power W. 10 of the Biggest Turbines.

[17] Musgrove P. Wind energy conversion: recent progress and future prospects. Solar \& wind technology. 1987;4(1):37-49. 
[18] Ahmed MA, AHMED F, Akhtar MW. Assessment of wind power potential for coastal areas of Pakistan. Turkish Journal of Physics. 2006;30(2):127-35.

[19] Al-Shemmeri T. Wind turbines: BookBoon; 2010.

[20] Pakistan Inflation Rate. Pakistan Bureau of Statistics, Statistics Division, Government of Pakistan, January 2016.

[21] Pakistan Interest Rate. State Bank of Pakistan, January 2016.

[22] Khan ZA, Wazir R, editors. Techno-economic study for $50 \mathrm{MW}$ wind farm in Pasni, coastal district of Balochistan-Pakistan using ARIMA models and RETScreen. Energy Systems and Policies (ICESP), 2014 International Conference on; 2014: IEEE.

[23] Said Z, Mehmood A. Standalone photovoltaic system assessment for major cities of United Arab Emirates based on simulated results. Journal of Cleaner Production. 2016. 